\title{
Influence of Strategic Orientation on SMEs Access to Finance in Nigeria
}

\author{
Ibrahim Murtala Aminu ${ }^{1} \&$ Mohd Noor Mohd Shariff ${ }^{1}$ \\ ${ }^{1}$ College of Business, Universiti Utara Malaysia, Sintok, Malaysia \\ Correspondence: Ibrahim Murtala Aminu, College of Business, Universiti Utara Malaysia, 06010 Sintok, \\ Malaysia. Tel: 60-16-970-1066. E-mail: murtalaaminuibrahim@gmail.com
}

Received: November 5, 2014

Accepted: December 9, 2014 Online Published: January 14, 2015

doi:10.5539/ass.v11n4p298

URL: http://dx.doi.org/10.5539/ass.v11n4p298

\begin{abstract}
The paper examined the influence of EO, MO, LO, and TO on SMEs financial capital accessibility in Nigeria. The purpose of this paper is to establish the role of firm strategic orientation in helping SMEs improve their financial access. A total of 362 questionnaires from SMEs in North Western Nigeria were used in this study. Partial Least Squares Structural Equation Modeling (PLS-SEM) was used to test the study hypotheses. Using SmartPLS 3.0 the findings indicates that strategic orientations are important drivers of firm success to finance. The result further suggests that SMEs who configured and utilized their strategic activities are more likely to get more cash flow, profit and retained earnings and will obtain a loan from external sources. To get an adequate financial capital SMEs need to improve their marketing activities, learn more from their experience and environment and lastly produce product with high technological improvement. At the same time they should avoid too much emphasis on taking risky business decision and investments.
\end{abstract}

Keywords: entrepreneurial orientation, market orientation, learning orientation, technology orientation, SMEs access to finance

\section{Introduction}

According to World Bank (2013), Small and Medium Enterprises (SMEs) contribute to the creation of employment which reduces regional inequalities between urban and rural areas. SMEs are the enging of economy through developing process and become large corporations. More so, CBN (2003) states that SMEs contribute to the employment generation, as it is one of the sectors that provide industrial employment in Nigeria. Because of their level of creativity, SMEs exploited the local raw materials that do not require high level technology to process, this provide an effective means of mitigating rural-urban migration and resource utilization. According to Osotimehin, Jegede, Akinlabi and Olajide (2012), SMEs are very fundamental for economic development. They contribute greatly to the economic and social improvement of the nation. Consequently, boosting the SMEs activities and government policies must go hand in hand to improve the growth and development of SMEs. To round it up, SMEs contribute about less than $46 \%$ to the GDP and $25 \%$ to employment in Nigeria, which indicate low performance of the sector (Ndumanya, 2013).

In recent times, there is growing agreement that a better access to finance for SMEs can enhance their performance and in turn have private and socioeconomic benefit on the nation's economy (Kumar, 2005). Hence, access to important resources such as finance is one of the major factor that encourages SMEs business activities in any economy (Kelley, Singer, \& Herrington, 2012; Xavier, Kelley, Kew, Herrington, \& Vorderwülbecke, 2013). However, accessibility of financing can influence SMEs performance in two ways. According to Margaritis and Psillaki (2010), high level of leverage positively influence superior firm performance of a firm. Then again, high indebtedness may leads to product market underperformance (Campello, 2006).

There is considerable confirmation to support the argument that SMEs, in specific, confront various hindrances and issues in obtaining financial resources (Cassar \& Holmes, 2003). Likewise, evidence shows that one of the significant causes for SMEs feeble development is the absence of financial access (Amorós \& Bosma, 2014; Rogerson, 2008). Access to finance is fundamental to the operation of the SMEs in a variety of ways, Kyophilavong (2011) confirm that access to finance is among the top obstacles to running SMEs compared to the cost of the finance. Similarly, without sufficient access to finance, SMEs performance will be extremely difficult to achieve such as growth, employment generation, profitability, export performance, efficiency, 
productivity and returns (Harvie, Oum, \& Narjoko, 2011). In developing country like Nigeria, SMEs are constrained in accessing financial resources and other financial assets. According to Mohammed and Obeleagu-nzelibe (2014), access to financing, concessional taxation, were found to be major causes for SMEs failures in Nigeria. However, getting sufficient financial resources is determine by the firm operation and strategic activities (Mazanai \& Fatoki, 2012; Rahaman, 2011; Steinerowska-streb \& Steiner, 2014). Therefore, configuring operative strategic orientation may enable SMEs improve their internal finances and attract external investors.

Despite growing interest in the role of strategic orientation of SMEs access to finance there is little attention and empirical literature on the impact of strategic orientation on access to finance. Studies such as Fatoki and Asah (2011) reveal that firm and entrepreneurial characteristics have impact on access to debt finance by SMEs. Similarly, entrepreneurial orientation (EO) as strategic orientation of a firm influence firm accessibility of finance (Zampetakis, Vekini, \& Moustakis, 2011). Additionally, Fatoki (2012) reports similar finding that SMEs access to debt depend on firm EO. However, there are few studies that show the relationship among the firms' strategic activities such as entrepreneurial orientation (EO), market orientation (MO), learning orientation (LO), technology orientation (TO) and firms' financial availability. Therefore, this study will address the aforementioned gap by examining the influence of EO, MO, LO and TO on SMEs access to finance in Nigeria. The remainder of this paper is organized as follows: Firstly, based on the review of the previous literature on access to finance, strategic orientation, the hypotheses of the study were formulated and research framework was presented in Figure 1. Secondly, the methodology, analysis of data as well as the empirical results was presented. Finally, the paper ends with a discussion of the implications, the limitations, and future research.

\section{Literature Review}

\subsection{Access to Finance}

According to Kelley et al. (2012), access to financial resources refer to the availability of financial capital and other financial services to SMEs. Similarly, Bouri et al. (2011) define access to finance as the availability of financial resources (internal, debt and equity) for SMEs. It also refers to financial services provided by financial institution (SMEDAN, 2012). Access to financing refers to the difference between SMEs demand for financial resources and supply of the necessary financial resources (Mazanai \& Fatoki, 2012). In a wider definition access to finance can be defined as the lack of financial and non-financial barriers in accessing financial resources and services. In other words, it is the extent to which financial resources and services are available to users at reasonable cost of capital (Ganbold, 2008). Thus, this study conceptualizes access to finance as the possibility of the enterprises to obtain financial resources (internal and external) with minimal or absent of financial and non-financial barriers.

It has been reported that most SMEs in developing economies are restricted in accessing finances, though the opaqueness nature of the firms may results in this serious constraints of accessing external financing and consequently affect their performance (Beck, Demirgüç-Kunt, \& Maksimovic, 2008). Several studies indicate that productivity of small businesses depends largely on its access to capital (Frank, Kessler, \& Fink, 2010; Wiklund \& Shepherd, 2005; Zampetakis et al., 2011). Mazanai and Fatoki (2012) reveal that access to finance is directly related to the performance of SMEs. Thus, the lack of finance upset the full potentials of SMEs as an economic driver. Batra, Kaufmann and Stone (2003) state that access to finance improve firms to grow and develop. They further argue that access to finance facilitates firm performance through innovation, new market, reduction in risk and improves entrepreneurial activity and firm growth.

It has been contended that most SMEs in developing economies are restricted in accessing finances, which invariably affecting their growth and development. For instance, one of the most severe problems facing SMEs in the developing world is access to finance (United Nations Industrial Development Organization [UNIDO], 2007). Therefore, inability of SMEs to access finance can be a restriction for their development. Although, the uncertainties typically associated with SMEs contributes to the difficulty for lenders to assess the risk of an investment (Dobbs \& Hamilton, 2007). Beck \& Demirguc-Kunt (2006) further explain that financial insufficiencies problem might prevent SMEs from growing and achieve their best performance. It also explains the inability of SMEs to influence economic development. Consequently, most of the SMEs rate access to finance as their major constraint to achieve superior performance (Bouri et al., 2011). Therefore, inadequate access to finance is one of the critical issues responsible for gross low performance of SMEs in Nigeria.

In a note shell, access to finance is one of the critical issues responsible for gross low performance of SMEs in Nigeria (SMEDAN, 2012). At first, SMEs in Nigeria typically don't have sufficient information in regards to accessibility of financial alternatives that could be harnessed. Secondly, the intricate, formalized, and high 
administrative procedures demoralize SMEs owners to make utilization of external financing. Thirdly, and above all SMEs activities, operations and strategies are not adapted towards enhancing their sales volume and profit which affect the external financiers' decisions. From this viewpoint, the restriction of their strategic orientation leads Nigerian SMEs to find it very hard to have enough cash flow, make sound investments and business growth strategies which could persuade external financiers to provide finances.

However, past studies have shown that SMEs lack of access to finance is related to SMEs peculiar characteristics, operation and strategic activities (Mazanai \& Fatoki, 2012). Access to financial resources determines SMEs success all through the diverse stages of their development. In that capacity, if a business has insufficient financial assets, it is more difficult for the enterprise to enter the market. Therefore, in these circumstances picking up an aggressive position and getting target customers may take more of a chance than for a venture with accessible financial capital. In a more established stage getting sufficient financial resources is determine by the firm peculiar characteristics, process and strategic activities which further affect the development of the enterprise (Steinerowska-streb \& Steiner, 2014). On these grounds issues identified with rising financing, is severe in SMEs due their nature of business operations and strategies hence, lead to numerous failures in SMEs.

\subsection{Strategic Orientation}

Building effective strategies is central to any firm as it enables it to achieve and maintain a competitive advantage. There is no precise definition of strategic orientations, as several authors attributed different meanings to the concept. Strategic orientations are organizational culture and complex abilities that can lead to better performance (Zhou et al., 2005). Strategic orientation refers to how an organization responds to environmental influences (Manu \& Sriram, 1996). So in order to survive organizations require combination of various strategies that are appropriate for rapid environmental changes. Strategic orientations refer to the organizational believes, values and principles that guide the managerial activities, as well as the resource utilization of the organization (Noble, Sinha, \& Kumar, 2002). Similarly, Gatignon and Xuereb (1997) conceptualize strategic orientation as the strategic activities carried out by the firm to develop and improve organizational activities for superior performance.

Due to increasingly short supply of financial capital, businesses in general need to utilize their organisational resource including strategic orientations to improve their financial requirements. Aktan and Bulut (2008) found that strategic activities positively affect the firms' financial access in the future. Similarly, firms with better strategies firm will have more access to financing and ought to have the ability to enhance their performance (Achleitner, Braun, \& Kohn, 2011). In other words firm strategic activities improve firm's cash flows, sales volume and profit which could increase the availability of financing (Ghimire \& Abo, 2013; Pandula, 2011). They argue that extent of financing and the choice of capital sources are both driven by a multitude of firm strategic abilities. Thus, ability of SMEs to get required business capital, rely on various firm strategies. SMEs that create effective strategic orientation can make more returns and profits and attract more external finances (Cheng, Ioannou, \& Serafeim, 2014). Subsequently, Ganbold (2008) point out that firm's failure to utilize principles that will direct and influence viable behaviours and activities are a significant reason impeding SMEs to get obliged financial resources. Specifically poor strategic actions in SMEs are one of the primary reasons that SMEs could not access finance.

However, there are broad strategic orientations options available to a firm, but ability to configure and utilize the available strategic orientations will give firm better financial capital access. Entrepreneurial, market, learning and technology orientations as organizational resources found to be good strategies that can improve firm financial performance that will ultimately affect its financial access. For instance, firm with better EO can have more access to fund (Zampetakis et al., 2011) and debt (Fatoki, 2012). In addition, entrepreneurial characteristics found to have positive influence on SMEs access to debt (Fatoki \& Asah, 2011). Likewise, entrepreneurial skills enhance better access to resources including financial resources (Mohammed \& Obeleagu-nzelibe, 2014). Since the inclination to take less secure, proactive and creative choices are very high. Additionally, as important firm resources MO can improve firm access to finance. Nikoomaram and Ma'atoofi (2011) report that MO influence firm ability to generate more profit. This can also be seen in Baker and Sinkula (2009) that there is positive link between MO and firm profitability. Furthermore, being market-oriented firm can generate high income, specifically through learning from the environment (Kropp, Lindsay, \& Shoham, 2006). Firm with technological prevalence can enhance their capability and their ability to have more funds. The products and services will offer themselves in the market, more particularly with great market-learning orientation concept. In conclusion, as access to finance is important for SMEs, it evidently depend on the firm strategies (Cheng et al., 2014; Ghimire $\&$ Abo, 2013). Based on this premise it is expected that EO, MO, LO, and TO can improve SMEs access to finance. Hence, this study posits that: 
H1 There is a positive relationship between EO and SMEs access to finance in Nigeria.

$\mathrm{H} 2$ There is a positive relationship between MO and SMEs access to finance in Nigeria.

H3 There is a positive relationship between LO and SMEs access to finance in Nigeria.

$\mathrm{H} 4$ There is a positive relationship between TO and SMEs access to finance in Nigeria.

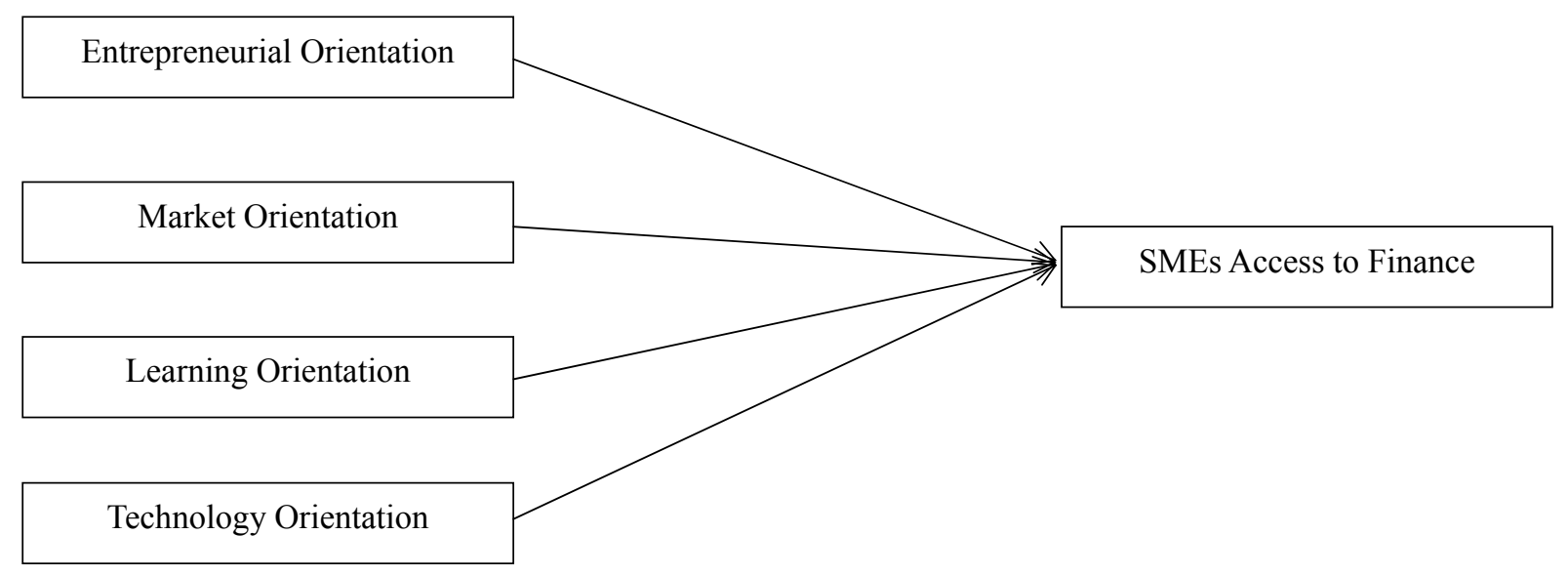

Figure 1. Research framework

\section{Method}

In line with the suggestion of Churchill (1979), measurements were adapted from previous studies to use in the current research context. Access to finance items were adapted from (Martin, Cullen, Johnson, \& Parboteeah, 2007), EO (Hakala \& Kohtamäki, 2011), MO (Suliyanto \& Rahab, 2012), LO (Farrell, Oczkowski, \& Kharabsheh, 2008) and TO (Spanjol, Qualls, \& Rosa, 2011). Survey research was used in this study and questionnaire was adapted to gather information from sampled SMEs. All the 3,671 SMEs operating in North Western Nigeria constitute the population of the study. Based on Dillman (2007) a total of 348348 SMEs were selected using stratified random sampling. However, the smaple was increased to 522 based on the suggestion of Salkind (1997).

Furthermore, a 56 items questionnaire was self-administered in Kano, Kaduna and Sokoto states of Nigeria. The study adopted 7 point Likert type for all the items to measure the responses of the respondents. Partial Least Squares-Structural Equation Modeling (PLS-SEM) was adopted for this study because it is well enhanced to be used as a research tool in marketing, strategic management and other social (Hair, Ringle, \& Sarstedt, et al., 2011; Hair Jr, Sarstedt, Hopkins, \& Kuppelwieser, 2014; Reinartz, Haenlein, \& Henseler, 2009).

\section{Results}

\subsection{Assessment of Measurement Model}

To start with, common method bias was assessed using Harman's single factor test. The 56 items factor analysis revealed that there was more than one factor accounting for the variance. The result produced 16 distinct factors and the first factor accounts for only $21.61 \%$ of the total variance. Therefore, problem of common method bias is not likely to be an issue as argued by Podsakoff et al., (2003) and Lowry and Gaskin (2014) that common method bias is present when single factor is explaining more than $50 \%$ of the variance.

Furthermore, reliability and validity are the two main criteria used in PLS-SEM analysis to evaluate the outer model (Hair Jr., Hult, Ringle, \& Sarstedt, 2013; Hulland, 1999; Ramayah, Lee, \& In, 2011). The reliability is assessed using Composite Reliability (CR) while validity is assessed using convergent validity Average Variance Extracted (AVE), and discriminant validity using Fornell-Larcker criterion and indicator's outer loadings. Accordingly, the Figure 2 and Table 1 indicates that the CR value in this study is between 0.84 and 0.94 , this indicate adequate internal consistency (Nunnally \& Bernstein, 1994). Additionally, all CR values exceeded the suggested threshold value of 0.70 (Hair et al., 2013; Henseler, Ringle, \& Sinkovics, 2009). 
Table 1 . Loadings, reliability and convergent validity values

\begin{tabular}{|c|c|c|c|c|c|}
\hline Constructs & Items & Loading & $\mathbf{C R}$ & $\overline{\text { AVE }}$ & Discriminant Validity? \\
\hline \multirow{5}{*}{ Access to Finance } & FAF1 & .64 & \multirow{5}{*}{.84} & \multirow{5}{*}{.52} & \multirow{5}{*}{ Yes } \\
\hline & FAF2 & .85 & & & \\
\hline & FAF3 & .66 & & & \\
\hline & FAF7 & .69 & & & \\
\hline & FAF8 & .72 & & & \\
\hline \multirow{7}{*}{ Entrepreneurial Orientation } & BEO10 & .86 & \multirow{7}{*}{.90} & \multirow{7}{*}{.57} & \multirow{7}{*}{ Yes } \\
\hline & BEO11 & .75 & & & \\
\hline & $\mathrm{BEO} 12$ & .64 & & & \\
\hline & $\mathrm{BEO} 2$ & .73 & & & \\
\hline & $\mathrm{BEO} 3$ & .77 & & & \\
\hline & BEO4 & .69 & & & \\
\hline & BEO9 & .84 & & & \\
\hline \multirow{8}{*}{ Market Orientation } & CMO10 & .77 & \multirow{8}{*}{.89} & \multirow{8}{*}{.62} & \multirow{8}{*}{ Yes } \\
\hline & CMO11 & .77 & & & \\
\hline & CMO12 & .77 & & & \\
\hline & CMO13 & .72 & & & \\
\hline & CMO6 & .73 & & & \\
\hline & $\mathrm{CMO} 7$ & .71 & & & \\
\hline & CMO8 & .74 & & & \\
\hline & CMO9 & .69 & & & \\
\hline \multirow{5}{*}{ Learning Orientation } & DLO1 & .78 & \multirow{5}{*}{.91} & \multirow{5}{*}{.54} & \multirow{5}{*}{ Yes } \\
\hline & DLO2 & .87 & & & \\
\hline & DLO3 & .87 & & & \\
\hline & DLO4 & .76 & & & \\
\hline & DLO5 & .64 & & & \\
\hline \multirow{9}{*}{ Technology Orientation } & ETO10 & .79 & \multirow{9}{*}{.94} & \multirow{9}{*}{.63} & \multirow{9}{*}{ Yes } \\
\hline & ETO11 & .76 & & & \\
\hline & ETO3 & .84 & & & \\
\hline & ETO4 & .86 & & & \\
\hline & ETO5 & .81 & & & \\
\hline & ETO6 & .72 & & & \\
\hline & ETO7 & .80 & & & \\
\hline & ETO8 & .80 & & & \\
\hline & ETO9 & .76 & & & \\
\hline
\end{tabular}

Note: $\mathrm{CR}=$ Composite Reliability, AVE $=$ Average Variance Extracted

Table 2. Discriminant validity

\begin{tabular}{llllll}
\hline Constructs & AF & EO & MO & LO & TO \\
\hline Access to Finance & $\mathbf{. 7 2}$ & & & & \\
Entrepreneurial Orientation & .25 &. $\mathbf{7 6}$ & & & \\
Market Orientation & .33 & .72 &. $\mathbf{7 4}$ & & \\
Learning Orientation & .24 & .09 & .21 & $\mathbf{. 7 9}$ & \\
Technology Orientation & .42 & .67 & .25 & .60 & $\mathbf{. 8 0}$
\end{tabular}

Note: The bolded values represent square root of Average Variance Extracted (AVE), AF=Access to Finance, $\mathrm{EO}=$ Entrepreneurial Orientation, $\mathrm{MO}=$ Market Orientation, $\mathrm{LO}=$ Learning Orientation, $\mathrm{TO}=$ Technology Orientation 
Next is convergent validity, all AVE values shown in Table 1 are above the threshold value of 0.50 , this indicates convergent validity of the measurement in this study (Hair et al., 2013). Finally, in this study two popular approaches for assessing the constructs' discriminant validity were used. This include Fornell and Larcker (1981) criterion and examination of cross loadings (Hair et al., 2013). Table 2 shows that each construct's square root of AVE is higher than its correlation with all of the other constructs. In addition, the result revealed that no indicator loaded higher on any opposing construct. In conclusion, both approaches evidently indicate that the study constructs show discriminant validity (Hair et al., 2013; Henseler et al., 2009).

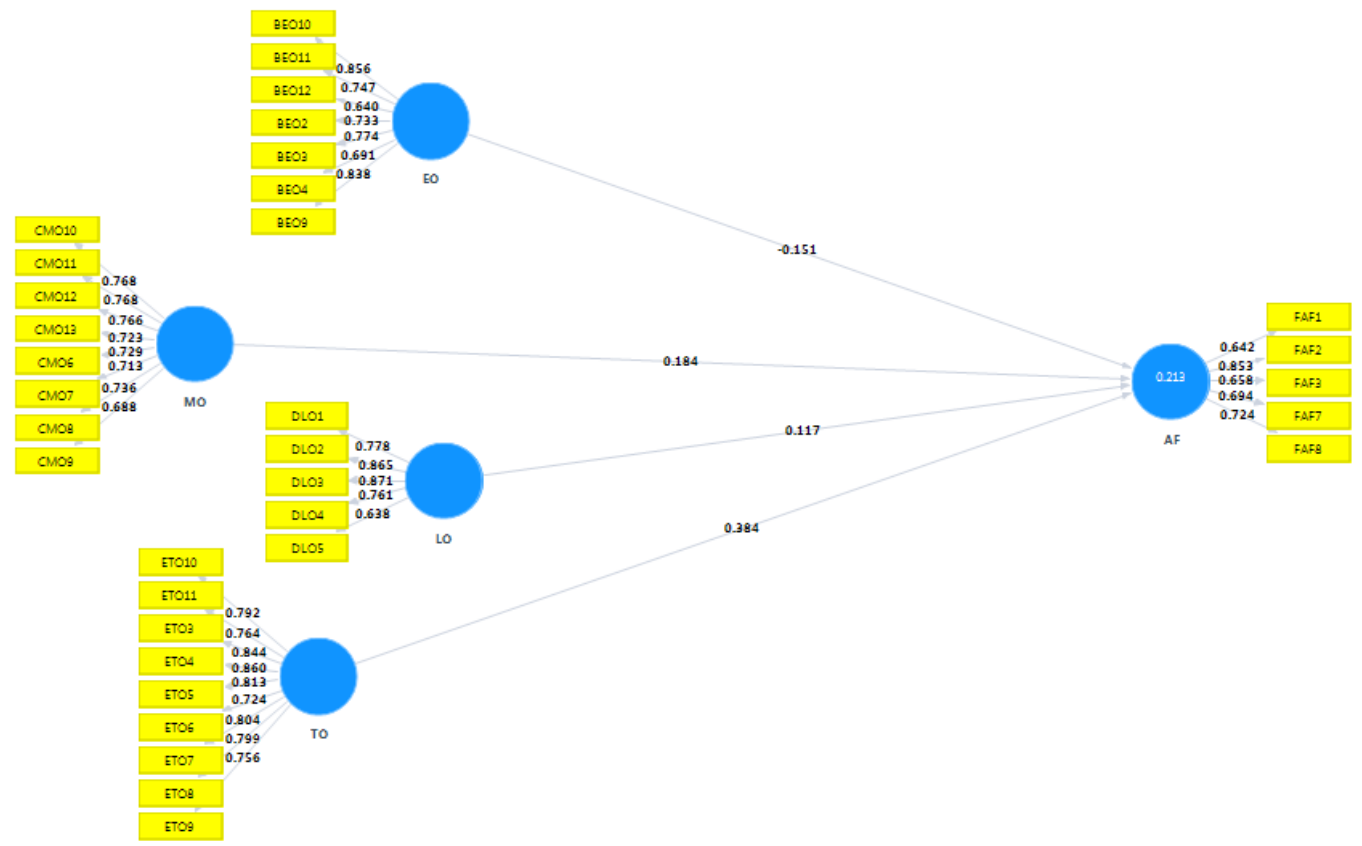

Figure 2. Measurement Model

\subsection{Assessment of Structural Model}

According to Hair Jr. et al. (2013), structural model assessment include collinearity examination, assessing the significance and relevance of the structural model relationships, $R^{2}$, effect size $\mathrm{f}^{2}$ and predictive relevance $\mathrm{Q}^{2}$. Thus, before assessing the structural model, this study assessed the collinearity among the exogenous variables. Table 3 shows that there no multicollinearity problem among the exogenous variable, since the VIF values are below 5 Hair Jr. et al. (2013).

Table 3. Collinearity using VIF

\begin{tabular}{lc}
\hline Constructs & VIF \\
\hline Entrepreneurial Orientation & 2.64 \\
Learning Orientation & 2.26 \\
Market Orientation & 1.11 \\
Technology Orientation & 1.99 \\
\hline
\end{tabular}

Based on satisfactory result of collinearity assessment, then the key criteria for assessing the structural model was assessed. Firstly, the structural model relationships were assessed using PLS-SEM Algorithm for the coefficient and PLS-SEM bootstrapping for the significance of the relationship. The SmartPLS 3.0 was used and original number of cases was used as the number of cases, 5000 sample was used for bootstrapping procedure (Hair, Ringle, \& Sarstedt, 2011; Hair et al., 2012; Hair et al., 2013; Henseler et al., 2009). Figure 3 Table 4 illustrates the results of relationship between the exogenous variables and endogenous variable of the PLS-SEM analysis. Specifically, the result of the structural model shows that there is significant negative relationship between EO and access to finance. Thus H1 was not supported. However, MO has a significant positive 
relationship with access to finance. Additionally, the result indicates significant positive relationship between LO and access to finance. Finally, the finding shows that TO have significant positive relationship with access to finance. Therefore, $\mathrm{H} 2, \mathrm{H} 3$ and $\mathrm{H} 4$ are supported.

Table 4. Results of hypotheses testing

\begin{tabular}{llllll}
\hline Hypotheses & Path Coefficient & Standard Error & T Statistics & P-Value & Decision \\
\hline EO -> AF & -.15 & .09 & 1.68 & .05 & Not supported \\
LO -> AF & .12 & .05 & 2.45 & .01 & Supported \\
MO -> AF & .18 & .08 & 2.33 & .01 & Supported \\
TO - AF & .38 & .08 & 4.86 & .00 & Supported \\
\hline
\end{tabular}

$*: \mathrm{p}<0.1 ; * *: \mathrm{p}<0.05 ; * * * \mathrm{p}<0.01$

Then, $\mathrm{R}^{2}$ is another central criterion for the structural model's assessment, this study has an acceptable $\mathrm{R}^{2}$ value of 0.25 (Cohen, 1988). The effect size $\left(\mathrm{f}^{2}\right)$ result indicates EO has value of 0.01 , MO has value of 0.02 , LO has value of 0.02 and TO has value of 0.09 which all considered as small. However, Chin, Marcolin and Newsted (2003) stressed that even the minutest value of $\mathrm{f}^{2}$ should be considered as it can stimulate the endogenous variable in its certain ways. Finally, after running the blindfolding procedure (Hair et al., 2013; Henseler et al., 2009), the $Q^{2}$ value of 0.15 indicates the predictive relevance of the model.

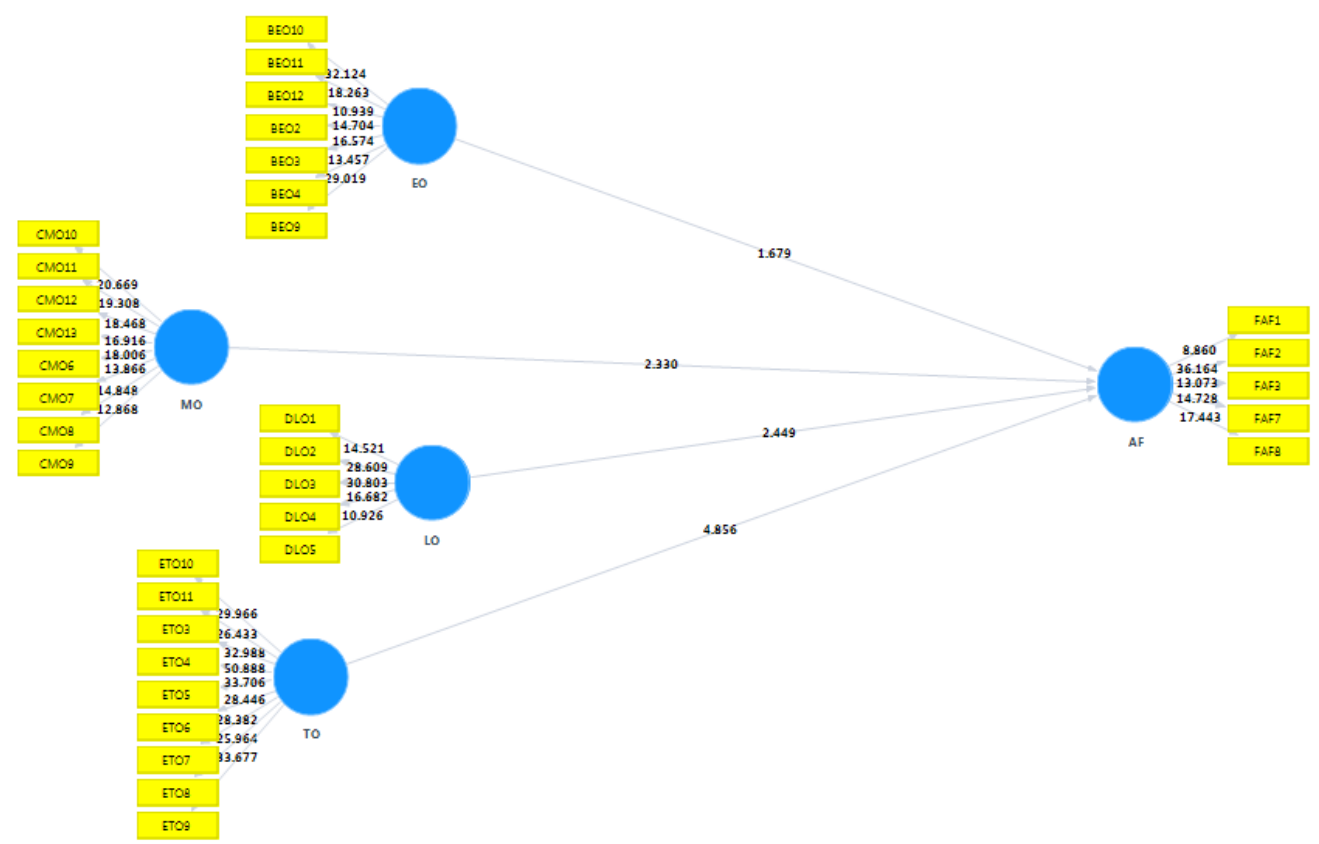

Figure 3. Structural model

\section{Discussion and Conclusion}

The objective of this study was to investigate the relationship between the four independent strategic orientation variables and their relationship with the access to finance. Firstly, H1 states that there is a positive relationship between EO and SMEs access to finance in Nigeria. The result shows that there is a significant negative relationship between EO and SMEs access to finance. Hence, contrary H1, this study did not find statistical evidence to support the hypothesis. Therefore, this finding suggests that the more SMEs perceive risk and unfriendliness of the environment the less they will involve in high return business activities. The risk taking, innovativeness and proactiveness activities are not quite easy to execute when the environment possess significant challenges (Tang \& Tang, 2012). Also, EO oriented SMEs explore risk and constant new opportunity seeking which may not guarantee success particularly in terms of financial achievement (Lumpkin \& Dess, 2001; Nybakk, 2012). Thus, the finding is not surprising, since Nigerian SMEs have likelihood of high perception of 
business risk and opportunities. Additionally, emphasis on EO activities as a only strategy of the firm may likely to lower firm profit and retained earnings (Baker \& Sinkula, 2009). In line with this argument, too much emphasis on EO limits firm's ability to achieve its objectives particularly financial goals (Tang, Tang, Marino, Zhang, \& Li, 2008). However, other fundamental reasons for this result include cultural, institutional and environmental nature of EO (Coulthard, 2007; Rauch, Wiklund, Lumpkin, \& Frese, 2009; Zahra \& Covin, 1995).

Second hypothesis $\mathrm{H} 2$ was supported as the regression result indicates that there is a positive relationship between MO and SMEs access to finance. The level of customer, competitor orientation and inter-functional coordination activities that SMEs have are positively related to their ability to get more cash flow which in turn affects their access to get financing in diverse ways. This finding further provides evidence that market oriented firms can satisfy customers better, tracking and reacting to customer needs and preferences and in turn enhance their internal finances and attract external investors. The finding links well with the argument that SMEs shortage to finance is related to their peculiar characteristics, business operations and strategies (Kyophilavong, 2011; Mazanai \& Fatoki, 2012; Steinerowska-streb \& Steiner, 2014; Terpstra \& Olson, 1993). Consistent with Turyahebwa, Sunday and Ssekajugo (2013), this result demonstrates that adopting strategic activities will help SMEs generate more profit that produce high retained earnings. Likewise, this findings is similar to Achleitner, Schraml and Tappeiner (2008) who argue that SMEs financing rest on the ability to manage bundle of strategic resources. To conclude, internal finances such as profit and retained earnings could increase when the SMEs emphases more on $\mathrm{MO}$ and it would also increase the likelihood to get external financing.

Proceeding in this way, $\mathrm{H} 3$ was also supported. This is another moving result, as expected the result has provide empirical evidence that there is relationship between LO and SMEs access to finance. This result is similar to the findings of preceding findings that the drivers of access to financial services in the SMEs industry are firm valuable resource such as experience, learning, social ties, training and intelligence (Alavera, Xiong, \& Xiong, 2010; Kamukama \& Natamba, 2013). The finding also supports the understanding of several studies that SMEs strategic activities improve access to funding (Ghimire \& Abo, 2013; Kyophilavong, 2011; Pandula, 2011; Steinerowska-streb \& Steiner, 2014).

Finally, the study found support for H4, that there is a positive relationship between TO and SMEs access to finance in Nigeria. Excitingly, the result of the regression analysis provide imprical evidence that there is a positive relationship between TO and SMEs access to finance. Closely to this finding, firm's technological resources found to be significantly and positively affectimg finances and tendency to access finance (Ndofor, Sirmon, \& He, 2011). This finding also concured with the view that SMEs activities and strategies affect access to both internal and external financing (Ghimire \& Abo, 2013; Pandula, 2011; Steinerowska-streb \& Steiner, 2014; Terpstra \& Olson, 1993). Based on this result, it is clear that TO as a firm valuable resource can improve financial accessibility of the firm.

To this end, this study recommends SMEs in Nigeria should utilized their risk, proactive and innovative activities of EO, but avoid too much concentration on these EO activities (Hakala \& Kohtamäki, 2011). In addition, this study suggests that SMEs owner-manager should adopt the culture MO since it can improve their internal finances and ability to get external finance. In other words, SMEs in Nigeria can pursue MO culture in order to reduce the financial constraints they are facing. Furthermore, SMEs in Nigeria should encourage learning and support individuals to utilized what they learned. Nigerian SMEs should consider ideas and opinions that are new and take appropriate response to the changes in the environment. In short, SMEs in Nigeria must recognize that learning is necessary for them to adapt to their environment for better financing opportunities. Finally, SMEs in Nigeria should pursue TO culture to develop their goods or services based on the firm's technical and do away with the status quo.

Notwithstanding, several important contributions discussed in this study concerning SMEs performance, it has some limitations that need to be identified and address. However, Harman single factor analysis established that the study is free from this problem, as potential problem in behavioral research future research can collect data from multiple participants (owners, managers and financiers) separately per enterprise, which can minimize the measurement errors. Secondly, this study focused on SMEs operating in northwestern Nigeria, thus, findings of this study should be carefully generalized to SMEs operating in another part of the country. Additionally, this research considers all type SMEs service and manufacturing, there is a need to examine the performance of SMEs based on the subsectors. Future research should consider examining SMEs access to finance in another part of the country and subsector activities which may provide more in-depth result. Thirdly, the present study relied on a single method of data collection. It will be of interest if future studies combine both quantitative and qualitative methods to investigate SMEs access to finance in Nigeria. Fourthly, the study used cross-sectional 
design which may restrict to prove causal relationships between the variables (Sekaran \& Bougie, 2010). To get more understanding on the subject matter and validate the findings from cross-sectional studies a longitudinal study is suggested for future research.

\section{References}

Achleitner, A. K., Braun, R., \& Kohn, K. (2011). New venture financing in Germany: Effects of firm and owner characteristics. Zeitschrift Für Betriebswirtschaft, 81(1), 263-294. http://dx.doi.org/10.1007/s 11573-011-0441-3

Achleitner, A. K., Schraml, S., \& Tappeiner, F. (2008). Private equity minority investments in large family firms: What influences the attitude of family firm owners? (No. 2008-12) (pp. 1-27).

Aktan, B., \& Bulut, C. (2008). Financial performance impacts of corporate entrepreneurship in emerging markets: A case of Turkey. European Journal of Economics, Finance and Administrative Sciences, (12), 69-79.

Alavera, O., Xiong, L., \& Xiong, X. (2010). Social capital and access to bank financing: The case of chinese entrepreneurs. Emerging Markets Finance and Trade, 48(1), 55-69. http://dx.doi.org/10.2753/ REE1540-496X480103

Amorós, J. E., \& Bosma, N. (2014). Global Entrepreneurship Monitor GEM 2013 Global report (pp. 1-104). Massachusetts.

Baker, W. E., \& Sinkula, J. M. (2009). The complementary effects of market orientation and entrepreneurial orientation on profitability in small businesses. Journal of Small Business Management, 47(4), 443-464. http://dx.doi.org/10.1111/j.1540-627X.2009.00278.x

Batra, G., Kaufmann, D., \& Stone, A. H. W. (2003). Investment climate around the world: Voices of the firms from the world business environment survey (pp. 1-178). Washington DC: World Bank Publications. http://dx.doi.org/10.1596/0-8213-5390-X

Beck, T., \& Demirguc-Kunt, A. (2006). Small and medium-size enterprises: Access to finance as a growth constraint. Journal of Banking \& Finance, 30(11), 2931-2943. http://dx.doi.org/10.1016/j.jbankfin. 2006.05.009

Beck, T., Demirgüç-Kunt, A., \& Maksimovic, V. (2008). Financing patterns around the world: Are small firms different? Journal of Financial Economics, 89(3), 467-487. http://dx.doi.org/10.1016/j.jfineco. 2007.10.005

Bouri, A., Breij, M., Diop, M., Kempner, R., Klinger, B., \& Stevenson, K. (2011). Report on support to SMEs in developing countries through financial intermediaries (pp. 2-48). Geneva: Dalberg Global Development Advisors 2011.

Campello, M. (2006). Debt financing: Does it boost or hurt firm performance in product markets? Journal of Financial Economics, 82, 135-172. http://dx.doi.org/10.1016/j.jfineco.2005.04.001

Cassar, G., \& Holmes, S. (2003). Capital structure and financing of SMEs: Australian evidence. Accounting \& Finance, 43(2), 123-147. http://dx.doi.org/10.1111/1467-629X.t01-1-00085

CBN. (2003). Overview of government's efforts in the development of SMEs and the emergence of Small and Medium Industries Equity Investment Scheme (SMIEIS). National Summit on SMIEIs Organized by the Bankers' Committee and Lagos Chambers of Commerce and Industry. Lagos: Central Bank of Nigeria $(\mathrm{CBN})$.

Cheng, B., Ioannou, I., \& Serafeim, G. (2014). Corporate social responsibility and access to finance. Strategic Management Journal, 35(1), 1-23. http://dx.doi.org/10.1002/smj.2131

Chin, W. W., Marcolin, B. L., \& Newsted, P. R. (2003). A partial least squares latent variable modeling approach for measuring interaction effects: Results from a Monte Carlo simulation study and an electronic-mail emotion/adoption study. Information Systems Research, 14(2), 189-217. http://dx.doi. org/10.1287/isre.14.2.189.16018

Churchill, G. A. (1979). A paradigm for developing better measures of marketing constructs. Journal of Marketing Research, XVI, 64-73. http://dx.doi.org/10.2307/3150876

Cohen, J. (1988). Statistical power analysis for the behavioral sciences (pp. 273-406). Hillsdale, New Jersey: Lawrence Erlbaum Associates.

Coulthard, M. (2007). The role of entrepreneurial orientation on firm performance and the potential influence of relational dynamism (No. 18/07) (pp. 1-12). Melbourne: Monash University Faculty of Business and Economics. 
Dillman, D. A. (2007). Mail and internet surveys: The tailored design method (2nd ed., Vol. 2, pp. 1-542). New York: John Wiley \& Sons, Inc.

Dobbs, M., \& Hamilton, R. T. (2007). Small business growth: Recent evidence and new directions. International Journal of Entrepreneurial Behaviour \& Research, 13(5), 296-322. http://dx.doi.org/10. 1108/13552550710780885

Farrell, M. A., Oczkowski, E., \& Kharabsheh, R. (2008). Market orientation, learning orientation and organisational performance in international joint ventures. Asia Pacific Journal of Marketing and Logistics, 20(3), 289-308. http://dx.doi.org/10.1108/13555850810890066

Fatoki, O. (2012). The impact of entrepreneurial orientation on access to debt finance and performance of small and medium enterprises in South Africa. Journal of Social Science, 32(2), 121-131.

Fatoki, O. O., \& Asah, F. (2011). The impact of firm and entrepreneurial characteristics on access to debt finance by SMEs in King Williams' town, South Africa. International Journal of Business and Management, 6(8), 170-180. http://dx.doi.org/10.5539/ijbm.v6n8p170

Frank, H., Kessler, A., \& Fink, M. (2010). Entrepreneurial orientation and business performance-A replication study. Schmalenbach Business Review, 62, 175-198.

Ganbold, B. (2008). Improving access to finance for SME: International good experiences and lessons for Mongolia (No. 438) (Vol. 438, pp. 1-64). Tokyo: Institute of Developing Economies.

Gatignon, H., \& Xuereb, J. M. (1997). Strategic orientation of the firm and new product performance. Journal of Marketing Research, XXXIV, 77-90. http://dx.doi.org/10.2307/3152066

Ghimire, B., \& Abo, R. (2013). An empirical investigation of Ivorian SMEs access to bank finance: Constraining factors at demand-level. Journal of Finance and Investment Analysis, 2(4), 29-55.

Hair Jr, J. F., Sarstedt, M., Hopkins, L., \& Kuppelwieser, V. G. (2014). Partial least squares structural equation modeling (PLS-SEM): An emerging tool in business research. European Business Review, 26(2), 106-121. http://dx.doi.org/10.1108/EBR-10-2013-0128

Hair Jr., J. F., Hult, G. T. M., Ringle, C., \& Sarstedt, M. (2013). A primer on partial least squares structural equation modeling (PLS-SEM) (pp. 1-307). SAGE Publications, Incorporated.

Hair, J. F., Ringle, C. M., \& Sarstedt, M. (2011). PLS-SEM: Indeed a silver bullet. The Journal of Marketing Theory and Practice, 19(2), 139-152. http://dx.doi.org/10.2753/MTP1069-6679190202

Hair, J. F., Ringle, C. M., Sarstedt, M., Haenlein, M., Kaplan, A. M., Eggert, A., ... Smirnova, M. (2011). Special issue on the use of Partial Least Squares (PLS) to address marketing management topics, 19(2).

Hair, J. F., Sarstedt, M., Ringle, C. M., \& Mena, J. A. (2012). An assessment of the use of partial least squares structural equation modeling in marketing research. Journal of the Academy of Marketing Science, 40(3), 414-433. http://dx.doi.org/10.1007/s11747-011-0261-6

Hakala, H., \& Kohtamäki, M. (2011). Configurations of entrepreneurial, customer and technology orientation: Differences in learning and performance of software companies. International Journal of Entrepreneurial Behaviour \& Research, 17(1), 64-81. http://dx.doi.org/10.1108/13552551111107516

Harvie, C., Oum, S., \& Narjoko, D. (2011). SMEs access to finance in selected East Asian economies. In D. Harvie, C. Oum, \& S. Narjoko (Ed.), Small and Medium Enterprises' (SMEs') Access to Finance in Selected East Asian Economies (pp. 41-82). Jakarta: ERIA Research Project Report 2010-14.

Henseler, J., Ringle, C. M., \& Sinkovics, R. R. (2009). The use of partial least squares path modeling in international marketing. New Challenges to International Marketing Advances in International Marketing, 20, 277-319.

Hulland, J. (1999). Use of Partial Least Squares (PLS) in strategic management research: A review of four recent studies. Strategic Management Journal, 20(2), 195-204. http://dx.doi.org/10.1002/(SICI)1097 -0266(199902)20:2<195::AID-SMJ13>3.0.CO;2-7

Kamukama, N., \& Natamba, B. (2013). Social capital: Mediator of social intermediation and financial services access. International Journal of Commerce and Management, 23(3), 204-215. http://dx.doi. org/10.1108/IJCoMA-02-2012-0013

Kelley, D. J., Singer, S., \& Herrington, M. (2012). The Global Entrepreneurship Monitor 2011 Global Report (pp. 1-37). Massachusetts.

Kropp, F., Lindsay, N. J., \& Shoham, A. (2006). Entrepreneurial, market, and learning orientations and international entrepreneurial business venture performance in South African firms. International Marketing Review, 23(5), 504-523. http://dx.doi.org/10.1108/02651330610703427 
Kumar, A. (2005). Measuring financial access through users' surveys core concepts, questions and indicators (pp. 1-54). Washington DC and London.

Kyophilavong, P. (2011). SMEs access to finance: Evidence from Laos. In C. Harvie, S. Oum, \& D. Narjoko (Eds.), Small and Medium Enterprises (SMEs) Access to Finance in Selected East Asian Economies (pp. 117-150). Jakarta: ERIA Research Project Report 2010-14.

Lowry, P. B., \& Gaskin, J. (2014). Partial Least Squares (PLS) Structural Equation Modeling (SEM) for building and testing behavioral causal theory: When to choose it and how to use it. IEEE Transactions on Professional Communication, 57(2), 123-146. http://dx.doi.org/10.1109/TPC.2014.2312452

Lumpkin, G. T., \& Dess, G. G. (2001). Linking two dimensions of entrepreneurial orientation to firm performance: The moderating role of environment and industry life cycle. Journal of Business Venturing, 16(5), 429-451. http://dx.doi.org/10.1016/S0883-9026(00)00048-3

Manu, F. A., \& Sriram, V. (1996). Innovation, marketing strategy, environment, and performance. Journal of Business Research, 35(1), 79-91. http://dx.doi.org/10.1016/0148-2963(95)00056-9

Margaritis, D., \& Psillaki, M. (2010). Capital structure, equity ownership and firm performance. Journal of Banking and Finance, 34(3), 621-632. http://dx.doi.org/10.1016/j.jbankfin.2009.08.023

Martin, K. D., Cullen, J. B., Johnson, J. L., \& Parboteeah, K. P. (2007). Deciding to Bribe: A Cross-Level analysis of firm and home country influences on bribery activity. Academy of Management Journal, 50(6), 1401-1422. http://dx.doi.org/10.5465/AMJ.2007.28179462

Mazanai, M., \& Fatoki, O. (2012). Access to finance in the SME sector: A South African perspective. Asian Journal of Business Management, 4(1), 58-67.

Mohammed, U. D., \& Obeleagu-nzelibe, C. G. (2014). Entrepreneurial skills and profitability of Small and Medium Enterprises (SMEs): Resource acquisition strategies for new ventures in Nigeria. In 25th International Business Research Conference (pp. 1-21). Cape Town.

Ndofor, H. A., Sirmon, D. G., \& He, X. (2011). Firm resources, competitive actions and performance: Investigating a mediated model with evidence from the in-vitro diagnostics industry. Strategic Management Journal, 32(6), 640-657. http://dx.doi.org/10.1002/smj.901

Ndumanya, N. (2013). Why SMEs' contribution to the nation's GDP is poor. Business Day. Lagos Nigeria.

Nikoomaram, H., \& Ma'atoofi, A. R. (2011). The effect of learning orientation on market orientation and performance in small sized firms: Evidence from Iran. European Journal of Social Sciences, 18(4), 632-642.

Noble, C. H., Sinha, R. K., \& Kumar, A. (2002). Market orientation and alternative strategic orientations: A longitudinal assessment of performance implications. The Journal of Marketing, 66, 25-39. http://dx.doi.org/10.1509/jmkg.66.4.25.18513

Nunnally, J. C., \& Bernstein, I. H. (1994). Psychometric theory (3rd ed.). New York: McGraw-Hill.

Nybakk, E. (2012). Learning orientation, innovativeness and financial performance in traditional manufacturing firms: A higher-order structural equation model. International Journal of Innovation Management, 16(5), 1-34. http://dx.doi.org/10.1142/S1363919612003873

Osotimehin, K. O., Jegede, C. A., Akinlabi, B. H., \& Olajide, O. T. (2012). An evaluation of the challenges and prospects of micro and small scale enterprises development in Nigeria. American International Journal of Contemporary Research, 2(4).

Pandula, G. (2011). An empirical investigation of small and medium enterprises' access to bank finance: The case of an emerging economy. In Proceedings of ASBBS Annual Conference (Vol. 18, p. 18).

Podsakoff, P. M., MacKenzie, S. B., Lee, J. Y., \& Podsakoff, N. P. (2003). Common method biases in behavioral research: A critical review of the literature and recommended remedies. The Journal of Applied Psychology, 88(5), 879-903. http://dx.doi.org/10.1037/0021-9010.88.5.879

Rahaman, M. M. (2011). Access to financing and firm growth. Journal of Banking and Finance, 35(3), 709-723. http://dx.doi.org/10.1016/j.jbankfin.2010.09.005

Ramayah, T., Lee, J. W. C., \& In, J. B. C. (2011). Network collaboration and performance in the tourism sector. Service Business, 5(4), 411-428. http://dx.doi.org/10.1007/s11628-011-0120-z

Rauch, A., Wiklund, J., Lumpkin, G. T., \& Frese, M. (2009). Entrepreneurial orientation and business performance: An assessment of past research and suggestions for the future. Entrepreneurship Theory and Practice, 33(3), 761-787. http://dx.doi.org/10.1111/j.1540-6520.2009.00308.x 
Reinartz, W., Haenlein, M., \& Henseler, J. (2009). An empirical comparison of the efficacy of covariance-based and variance-based SEM. International Journal of Research in Marketing, 26(4), 332-344. http://dx.doi.org/10.1016/j.jiresmar.2009.08.001

Rogerson, C. M. (2008). Tracking SMME development in South Africa: Issues of finance, training and the regulatory environment. Urban Forum, 19(1), 61-81.

Salkind, N. J. (1997). Exploring Research (3rd ed.). Upper Saddle River, NJ: Prentice Hall.

Sekaran, U., \& Bougie, R. (2010). Research methods for business: A skill building approach (5th ed., pp. 1-387). United Kindom: John Wiley \& Sons Ltd.

SMEDAN. (2012). Survey report on Micro, Small, and Medium Enterprises (MSMEs) in Nigeria. Abuja: Small and Medium Enterprises Development Agency of Nigeria.

Spanjol, J., Qualls, W. J., \& Rosa, J. A. (2011). How many and what kind? The role of strategic orientation in new product ideation. Journal of Product Innovation Management, 28(2), 236-250. http://dx.doi. org/10.1111/j.1540-5885.2010.00794.x

Steinerowska-streb, I., \& Steiner, A. (2014). An analysis of external finance availability on SMEs' decision making: A case study of the emerging market of Poland. Thunderbird International Business Review, 56(4), 373-386. http://dx.doi.org/10.1002/tie.21627

Suliyanto, S., \& Rahab, R. (2012). The role of market orientation and learning orientation in improving innovativeness and performance of small and medium enterprises. Asian Social Science, 8(1), 134-145.

Tang, J., Tang, Z., Marino, L., Zhang, Y., \& Li, Q. (2008). Exploring an inverted U-shape relationship between entrepreneurial orientation and performance in Chinese ventures. Entrepreneurship, 32(1), 219-239.

Tang, Z., \& Tang, J. (2012). Entrepreneurial orientation and SME performance in China's changing environment: The moderating effects of strategies. Asia Pacific Journal of Management, 29(2), 409-431. http://dx.doi.org/10.1007/s10490-010-9200-1

Terpstra, D., \& Olson, P. (1993). Entrepreneurial start-up and growth: A classification of problems. Entrepreneurship Theory and Practice, 17(3), 5-15.

Turyahebwa, A., Sunday, A., \& Ssekajugo, D. (2013). Financial management practices and business performance of small and medium enterprises in western Uganda. African Journal of Business Management, 7(38), 3875-3885.

UNIDO. (2007). Corruption prevention to foster small and medium-sized enterprise development: Providing anti-corruption assistance to small businesses in the developing world (No. 07-86953). Providing anti-corruption assistance to small businesses in the developing world (Vol. 1, pp. 1-23). Vienna: United Nations Industrial Development Organization.

Wiklund, J., \& Shepherd, D. (2005). Entrepreneurial orientation and small business performance: A configurationally approach. Journal of Business Venturing, 20(1), 71-91. http://dx.doi.org/10.1016/j. jbusvent.2004.01.001

World Bank. (2013). The little data book on private sector development. World Bank.

Xavier, S. R., Kelley, D., Kew, J., Herrington, M., \& Vorderwülbecke, A. (2013). Global Entrepreneurship Monitor GEM 2012 Global report (pp. 1-87). Massachusetts.

Zahra, S. A., \& Covin, J. G. (1995). Contextual influences on the corporate entrepreneurship-performance relationship: A longitudinal analysis. Journal of Business Venturing, 10(1), 43-58. http://dx.doi.org/10. 1016/0883-9026(94)00004-E

Zampetakis, L. a., Vekini, M., \& Moustakis, V. (2011). Entrepreneurial orientation, access to financial resources, and product performance in the Greek commercial TV industry. The Service Industries Journal, 31(6), 897-910. http://dx.doi.org/10.1080/02642060902960800

Zhou, K. Z., Kin, C., \& Tse, D. K. (2005). The effects of strategic orientations on technology-and market-based breakthrough innovations. Journal of Marketing, 69, 42-60. http://dx.doi.org/10.1509/jm kg.69.2.42.60756

\section{Copyrights}

Copyright for this article is retained by the author(s), with first publication rights granted to the journal.

This is an open-access article distributed under the terms and conditions of the Creative Commons Attribution license (http://creativecommons.org/licenses/by/3.0/). 